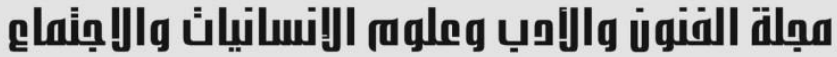 \\ Journal of Arts, Literature, Humanities and Social Sciences www.jalhss.com
}

Volume (68) June 2021

العدد (68) يونيو 2021

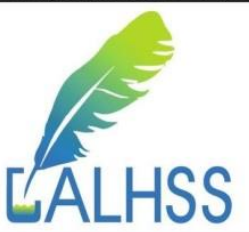

\section{Assessing Awareness of Medical Ethics among Tabuk University Students}

\author{
Ali Hussain Najmi \\ Associate Professor, Department of Education and Psychology, Vice-Dean of the Scientific Research \\ Deanship, University of Tabuk, Saudi Arabia \\ Email: a.najmi@ut.edu.sa \\ Abdel Mohsen Ibrahim Hashim \\ Professor, Department of Languages and Translation, University of Tabuk, Saudi Arabia \\ Email: a.ibrahim@ut.edu.sa \\ Mohammed Abdelraouf Attia \\ Professor, Department of Education Foundations, King Khaled University, Saudi Arabia \\ Email: mabdelraouf75@gmail.com
}

\begin{abstract}
Ethics education aims to help university students understand moral principles, and analyze and define their own values. The study aimed to determine the level of awareness of the medical ethics among the six undergraduate colleges at the University of Tabuk. The subjects were chosen using systematic sampling technique (response rate was 99.8\%). Majority of the students $(58.5 \%)$ mentioned that the source of their knowledge was from lectures/seminars/clinical discussions, while $20.7 \%$ derived the knowledge from mass media and (8.6\%) derived the knowledge from literature and medical journals as well. It was observed that $59 \%$ of undergraduates know about medical ethics, while 33\% don't know about medical ethics. Maximum number $(84.6 \%)$ of the university students agreed that ethical issues are very important in their lives. A high value $(56.8 \%)$ of ethics of healthcare practitioners was reported towards himself. A medium response was obtained from our responders with respect to well-reception of the patient, smiling at his face (56\%),listening well to the patient's complaint and understanding his suffering (54\%)and respect to the patient whatever his status (57\%)..There is a pressing need to implement the ethics education in all colleges in the University of Tabuk to understand moral principles and analyze and define their own values.
\end{abstract}

Keywords: Professionalism; Medical ethics; Knowledge attitude; Behavior; Medical students; professional ethics, University of Tabuk. 


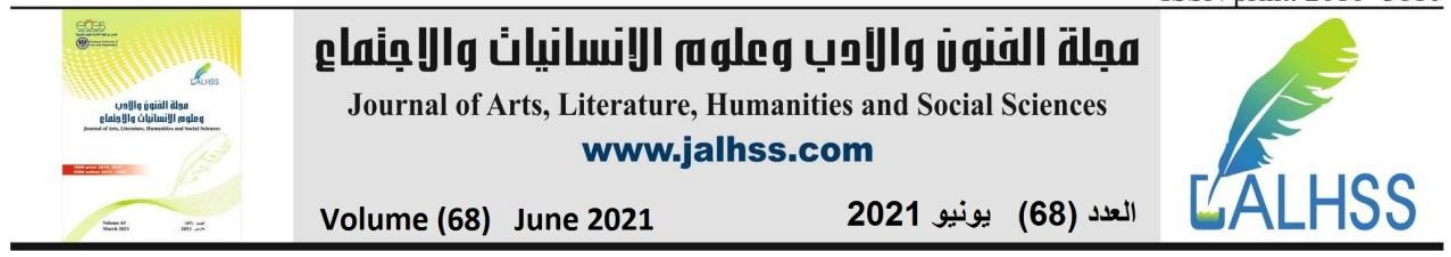

\section{INTRODUCTION:}

There is still no formal medical ethics curriculum being seriously implemented in many universities, colleges and institutions and medical schools. Medical ethics is not as a part of the curriculum in most of the colleges in the Tabuk and no curricular time has been assigned. The major reason can be the lack of institutional interest which may be related to the lack of trained teachers and the paucity of ethics educational resources, faculty and other infrastructures in these colleges and institutions. Currently, there are no extraordinary, indigenous and available standardized undergraduate medical ethics texts in the list of recommended textbooks within the Tabuk university system. While considering the importance of medical ethics, it is composed of four principles namely justice, autonomy, non-maleficence and beneficence. These principles can help medical practitioner, doctors, nursing and other health care workers to make decisions when reflecting on moral issues that arise at work. $(1,2)$ Knowledge of professional and medical ethics education need to be recognized as an independent and can be given a greater formal presence in the college ,school curriculum . (3)

Knowledge and practice of Medical ethics by healthcare professionals is an extremely mandatory and important issue in today's highly sophisticated and expensive medical treatment. Code of professional and medical ethics describes what is expected from healthcare professionals registered and licensed to practice medicine. It determines the principles that characterize good medical practice and clarify the standards of professional ethics expected from healthcare professionals by their professional peers, other health professionals and the community. Contemporary academic scholars cared a lot about the ethics of work during the 1970s and 1980s. This concern is due to the people's concern for the immoral behavior of the workers and the spread of news on many bribery, espionage, moral scandals, nepotism, disclosure of confidential information and other matters. Thus, the ethics of the profession are becoming more and more apparent at the present time, as people around the world are not repeating moral terms in relation to professions, such as rules and ethics, ethics, business ethics, management ethics and ethical responsibility Scientific studies. Ethics is the principle that allow to verify what is morally right and what is morally wrong in human action (4). It has been described as the science of morals and rules of conduct recognized in human life $(5,6)$. It determines the principles that characterize good medical practice and clarify the standards of professional ethics expected from medical doctors by their professional peers, other health professionals and the community (7).Different institutions are racing to issue a Code of Ethics. Since efficiency and results are the single focus of attention, and profit is the primary objective, ethics has become increasingly relevant, and even some government policies and bodies have made it their primary task to introduce new legislation that defines the ethics of work and all professions of different classes $(8,9)$. The health professions are of the humanitarian and moral professions that are based mainly on science and work, and must be exercised by those who are aware of and trained enough to exercise, and to take into account the circumstances and conditions of dealing with patients aimed at their absolute interest $(10,11)$. There is a growing interest in the ethics of the profession in 


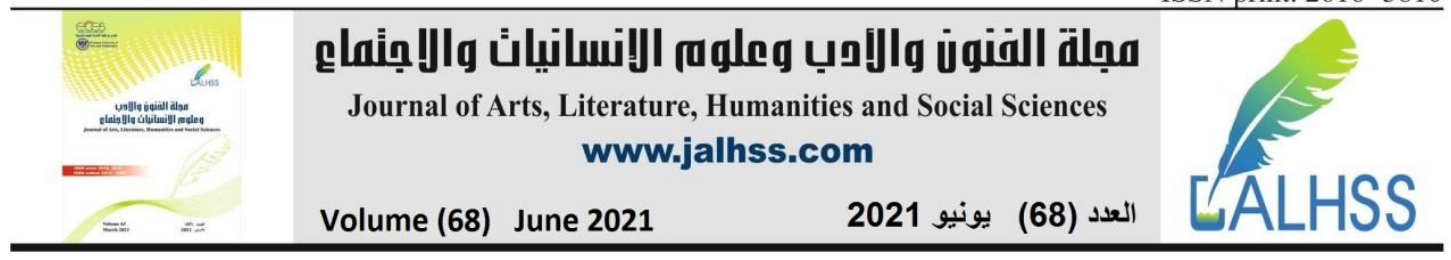

Islamic societies; Obviously, Islam holds its people to the standards of ethics, sincerity and mastery, and therefore it is the right of the members of the medical and health professions to stick to the profession ethics and regard it as a duty (12).

Muslim doctors have taken care of the ethics and ethics of the profession, and even wrote many works on it. For example, Abu Bakr Mohammed bin Zakaria al-Razi (313 $\mathrm{AH} /$ 925) wrote a great book entitled Ethics of the Health Practitioner,and this is Ibn Abu Abuqah (668 AH / 1270 AD), a great Islamic figure in the field of medicine, whose medical books included many of those ethics as seen in his book Eyes of News among Physicians $(13,14)$.From this perspective, the Saudi Commission for Health Specialties issued the "Ethics of the Health Practitioner" in order to educate the target groups about the tasks entrusted to them to achieve the best health professions (15). Although Islam, its scholars and contemporary societies emphasize the importance of adhering to the ethics of professions - in general, and the health professions in particular - the health field observant finds, in practice, that there are shortcomings in the commitment to ethics such as receiving the patient in a good way, smiling at the patient's face, Avoiding the inferiority of some patients, being cautious about committing legal infractions, not changing the deadlines of the patient, and not refraining from treating the patient. Nowadays not much stress is laid on imparting knowledge of medical ethics to undergraduate students in a colleges and institutions, where the attitude and knowledge in various fields of medicine take root among future doctors.

An unknown percentage of healthcare professionals, healthcare workers and physicians providing health care services do so unethically, with a wide variety of abuses such as: practising without required licences and registrations; practising without the proper educational qualifications; negligence; erroneous, over-charging; unwarranted or uncertain prescriptions, surgical procedures; treatments or monitoring: supervising, or conducting torture; and sexual misconduct with patients. $(16,17)$ There can be unethical disclosure of a patient's clinical history to researcher's, employers, attorneys, credit investigators, banks, and others; and sexual contact may be initiated by the practitioner with his or her patients. Practitioners may accept excessive fees or bribes for expert testimony, and they may make narcotics and other substances that can be misused available to those in their care. They may treat unreported gunshot wounds or perform illegal abortions. Some of the fatal diseases, incurable terminal conditions, stent implantation are susceptible to medical fraud. Some healthcare professionals, healthcare workers and physicians offer ineffectual cures for everything from cancer to baldness. The unethical medical practice has become a serious issue in the world now days and the effects of unethical medical practice has become wide reaching and harming many patients who come to hospitals in search of compassionate medical services (18). The increase in litigation against some healthcare professionals, healthcare workers and physicians is an immediate and hot issue $(19,20)$. Therefore, the aim of this research project was: developing a framework for raising the level of awareness among students of medical and health colleges at University of Tabuk of the ethics of the profession. The sub-goals of this goal are as follows 


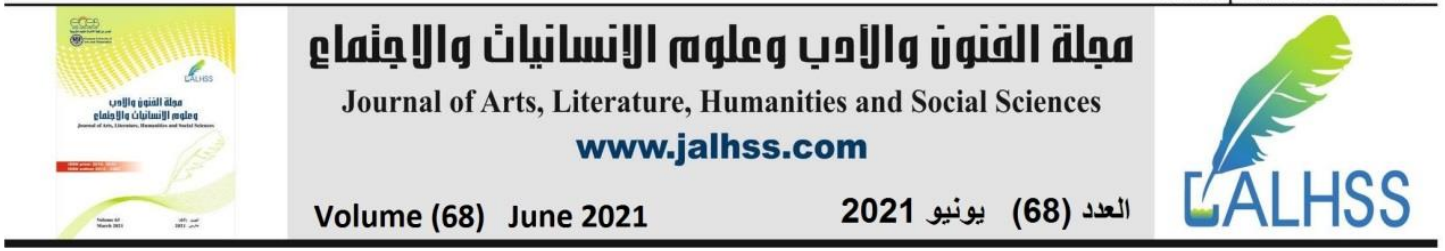

(a):Recognizing the level of awareness of students of medical and health colleges at Tabuk University this ethics.

(b): Finding out if there are statistically significant differences between the average responses of the students of the medical and health colleges at University of Tabuk about their level of awareness of the ethics of the profession due to the variables of: sex, college

(c): Presenting a proposed vision to enhance the awareness of students of medical and health colleges at Tabuk University of the ethics of the profession.

The main purpose of this work is to identify the ethical needs and ethical dilemmas fresh under medical and non-students to seek their suggestions to seek better educational approaches that can be applied in teaching medical ethics proposed by the medical students themselves throughout the teaching process. This study revealed the essential need for a model medical ethics curriculum that need to be implemented in the university colleges to learn and gain profound knowledge on moral reasoning and ethical decision making to be applied both horizontally and vertically across the whole years of university of Tabuk.

\section{Methodology:}

a) Cross Sectional Study:

The study was a cross sectional study carried out in the university in different colleges of university of Tabuk .A total of 641 students participated in this survey among which (479) $74.7 \%$ were females and (162) $25.3 \%$ were males as depicted in table No 1a. The majority of these undergraduate students $(50 \%)$ were aged between 20 and 24 years. All the respondents were Muslims, with the majority (99\%) belonging to the Tabuk of Saudi Arabia. The sample size was calculated using the formula for estimating single population proportion with the margin of error 5\%, the assumption of $95 \%$ confidence level and $31.1 \%$ of positive about importance of medical ethics $(21,22)$.

\section{b) Confidentiality:}

The confidentiality of the student responses was maintained and also anonymity of respondents was ensured. All data obtained from the subjects was kept secured and available only to the statistician.

\section{c) Participating colleges:}

The study was conducted in the university of Tabuk. Sir colleges participated in this study including College of pharmacy 82 , College of Nursing 141, Community college 50, College of Nursing 125, College of Medicine 77 and College of Medical Lab technology (MLT) 166 as depicted in table no 1. 


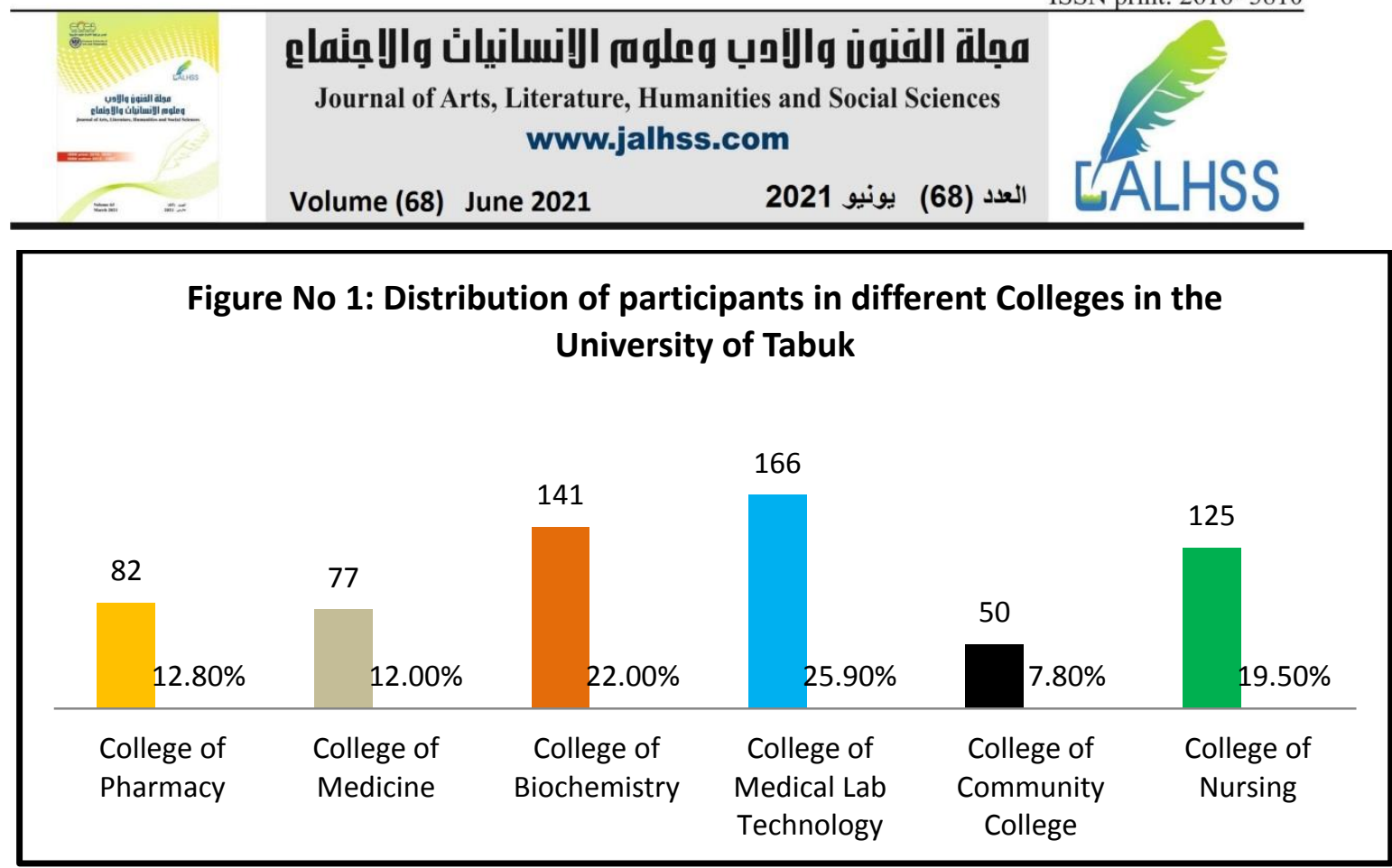

The survey was conducted on 641 students participated in this survey among which $74.7 \%$ participants were females and $25.3 \%$ were males. The study was conducted from September 2019 to January 2020 among medical and paramedical undergraduate students who were attending year (Ist $, 2^{\text {nd }}, 3$ rd, and $4^{\text {th }}$ academic years) in six colleges of university of Tabuk likely College of pharmacy, College of Nursing, Community college, College of Nursing, College of Medicine and College of Medical Lab technology (MLT).

d) Participants from colleges:

From the analysis it was found that majority of the respondents $25.9 \%$ belong to College of Medical Lab Technology followed by College of Biochemistry 22.0\%, College of Medicine 20\%, College of Nursing 19.5\%, and College of pharmacy $12.80 \%$ and Community College $7.8 \%$ as depicted in figure No 1 .

e) Nature of questionnaire:

A structured questionnaire on knowledge of principles of medical ethics, attitudes towards core values for guidance, attitudes regards to duties of doctors towards patients, attitudes towards learning medical ethics in the curriculum was distributed to the students. The questionnaire also included socio-demographic characteristics of students such as academic year, age, gender, ethnicity, nationality, scholarship status.

f) Distribution of the questionnaire among students:

To obtain information needed to fulfill the objectives of the research study, questionnaire was drafted. The questionnaire was distributed by the concerned investigators along with the concerned teacher or faculty member to the (Ist, 2nd, 3rd, and $4^{\text {th }}$ academic years) students in six colleges of university of Tabuk College of pharmacy, College of Nursing, Community college, College of Nursing, College of Medicine and College of Medical Lab technology (MLT).Before data collection, the purpose of the study was explained to the respondents. Participation was strictly voluntary and autonomy of the respondents was respected. Self-administered method for data collection was used and the students were given instruction if they agreed to participate in this study.

g) Collection of Data: 


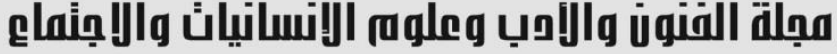 \\ Journal of Arts, Literature, Humanities and Social Sciences www.jalhss.com \\ Volume (68) June 2021 \\ العدد (68) يونيو 2021

Data was collected among 641 students using a well-designed questionnaire. The ethical values varies based on the individual perception, it has a high relation between the ethics and the code of awareness.

It was ensured that respondents understood the meaning of questions as well. Questionnaire included demographic details and several questions on everyday ethical issues. They were asked if they agreed or disagreed with certain statements concerning ethical conduct, awareness of ethical courses confidentiality, ethical issues, existence of ethics committee, teaching courses about profession. The respondents were asked to grade their responses on a 3 point likert scale, where the possible responses are agree, no opinion, or disagree. Collected data was entered in excel and results were expressed in proportions. Willingness to participate in the study was obtained from participants. Those who are on leave, refused to participate were excluded from the study.

\section{RESULTS:}

1) Socio-demographic characteristics and general Information:

A total of 641 students participated in this survey; 74.7\%) students were females and $25.3 \%$ were males as depicted in the table 1 . The study participants were from six colleges of university of Tabuk-College of pharmacy $82(12.8 \%)$, college of Medical Lab technology (MLT) 166(25.9\%), college of Nursing, 141(22\%) and college of Medicine 77 (12\%), Community college 50 (7.8\%) and college of Nursing 125 $(19.5 \%)$ as depicted in figure 1 and table no 1 .

Table No-1: Gender based distribution of participants

\begin{tabular}{|c|c|c|}
\hline Gender & Freq. & $\%$ \\
\hline Female & 479 & $74.7 \%$ \\
\hline Male & 162 & $25.3 \%$ \\
\hline Total & 641 & $100.0 \%$ \\
\hline
\end{tabular}

Table No-1b: Frequency of participants in different Colleges in University

\begin{tabular}{|c|c|c|}
\hline College of Pharmacy & 82 & $12.8 \%$ \\
\hline College of Medicine & 77 & $12.0 \%$ \\
\hline College of Biochemistry & 141 & $22.0 \%$ \\
\hline College of Medical Lab Technology & 166 & $25.9 \%$ \\
\hline College of Community College & 50 & $7.8 \%$ \\
\hline College of Nursing & 125 & $19.5 \%$ \\
\hline Total & 641 & $100.0 \%$ \\
\hline
\end{tabular}

2) Knowledge about medical ethics among university undergraduates

Among the university undergraduates, it was observed that $59 \%$ of undergraduates know about the medical ethics however 33\% don't know about medical ethics whereas $7.6 \%$ have no knowledge of medical ethics as depicted as depicted in figure no 2 . 


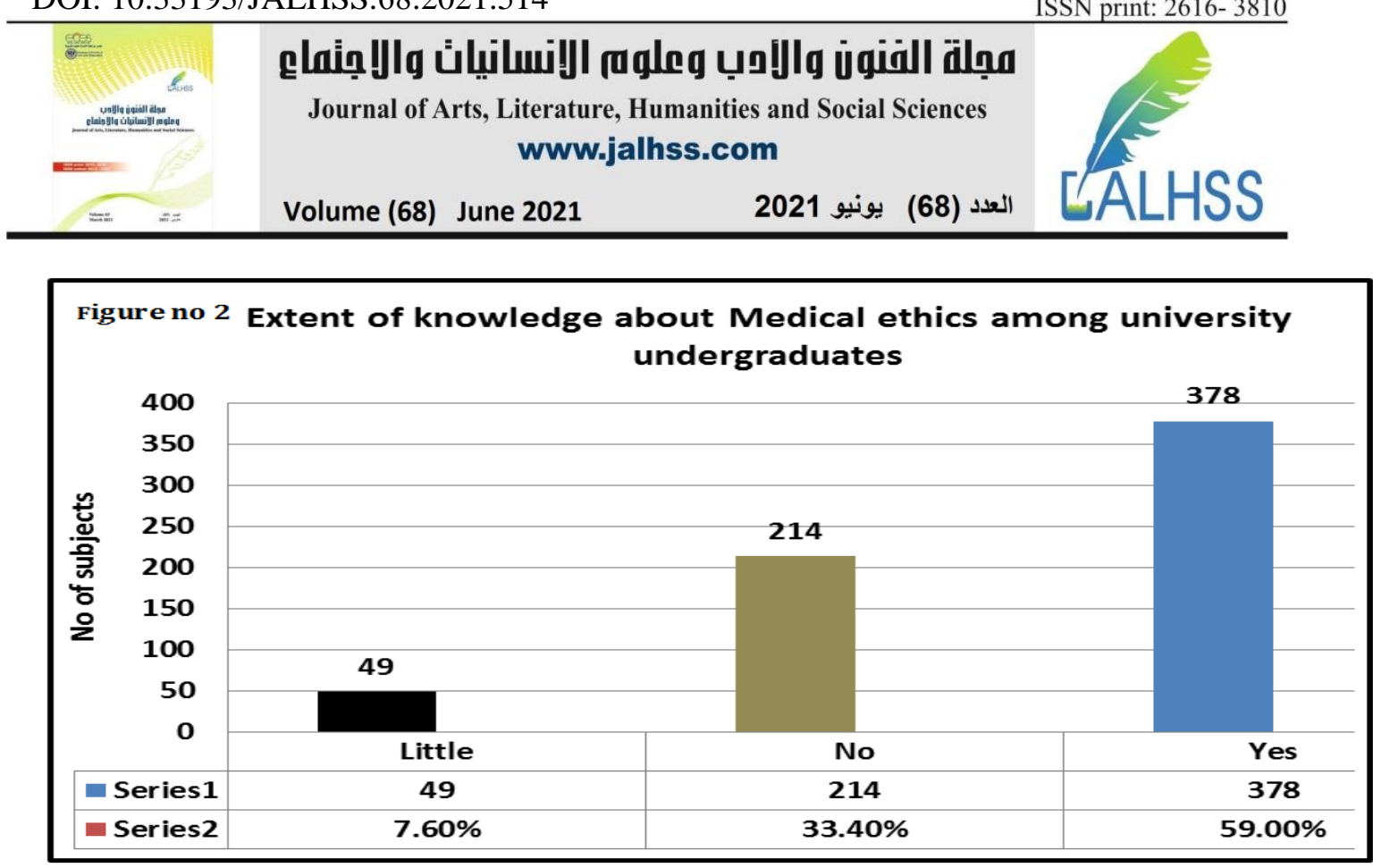

3) Importance of medical ethical issues among university undergraduates:

It was observed that the maximum number of university students agreed that ethical issues are very important in their lives. The responses of importance of ethical issues among the university undergraduates were 5\% unimportant, $2.5 \%$ somehow important, $12.3 \%$ important and $84.6 \%$ were very important. The least agreed upon the statement that the ethical issues are somehow important in their lives as depicted in the table 2.

\begin{tabular}{|l|c|c|}
\hline \multicolumn{3}{|c|}{ Table :2 How important are ethical issues in your profession } \\
\hline Unimportant & 3 & $0.5 \%$ \\
\hline Somehow important & 17 & $2.7 \%$ \\
\hline Important & 79 & $12.3 \%$ \\
\hline Very important & 542 & $84.6 \%$ \\
\hline Total & $\mathbf{6 4 1}$ & $\mathbf{1 0 0 . 0 \%}$ \\
\hline Ethics committee in your institution & 443 & $69.1 \%$ \\
\hline Do not know & 99 & $15.4 \%$ \\
\hline No & 99 & $15.4 \%$ \\
\hline Yes & 641 & \\
\hline Total & 321 & $50.1 \%$ \\
\hline $\begin{array}{l}\text { Has your institution held a conference, a symposium, a workshop, a seminar, or } \\
\text { have you presented a paper about profession ethics? }\end{array}$ \\
\hline Do not know & 181 & $28.2 \%$ \\
\hline No & 139 & $21.7 \%$ \\
\hline Yes & 641 & $100.0 \%$ \\
\hline Total & 39 & $39.2 \%$ \\
\hline Have you attended any course on your profession ethics in your college? & 251 & $60.8 \%$ \\
\hline No & 390 & \\
\hline Yes &
\end{tabular}




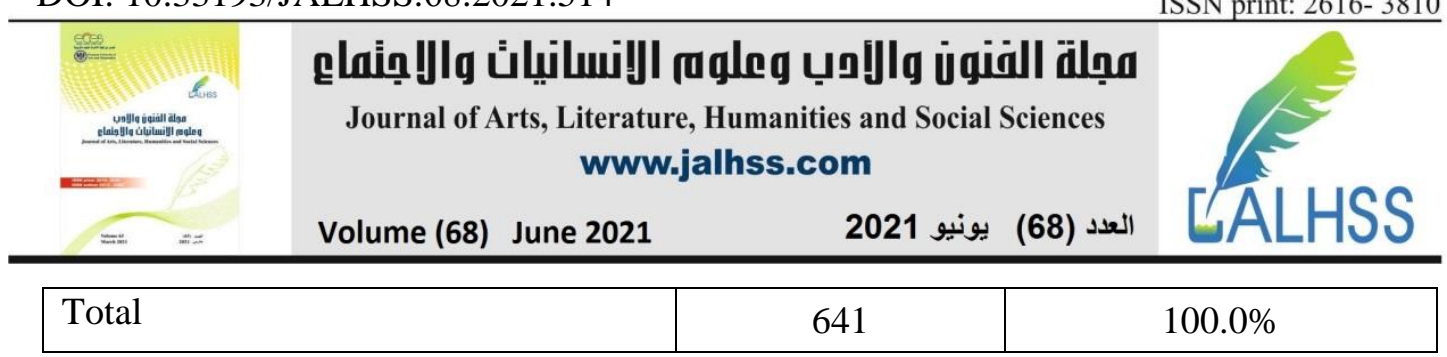

4) Existence of ethics committee:

More than 50\% university undergraduate's don't know about the about the existence of ethics committee in the university whereas $15.4 \%$ don't know and $15.4 \%$ said yes that they know about the existence of ethical committee in the campus as depicted in the table 2.

\section{5) Conferences, symposium, workshop, seminar on profession ethics:}

More than 50\% university undergraduates don't know about the conference, a symposium, a workshop, a seminar on profession of ethics conducted in the university. Only $21.7 \%$ university undergraduates knew about the meetings conducted on profession ethics and $28.2 \%$ said no. More than $60.8 \%$ university undergraduates attended any course on profession ethics in their college whereas $39.2 \%$ do not attended any course on profession ethics in their college depicted in the table 1 .

6) Sources of knowledge among university undergraduates:

Majority of the students $(58.5 \%)$ mentioned that the source of their knowledge was from lectures/seminars/clinical discussions, while $20.7 \%$ derived the knowledge from mass media and $(8.6 \%)$ derived the knowledge from literature and medical journals as well (Figure 3)

7) The health practitioner's Ethics towards the patients:

The health practitioner`s ethics towards the patients was evaluated by our university undergraduates and a medium value of ethics towards the patients was obtained as depicted in the Table 3. A medium response was obtained from our responders with respect to well-reception of the patient and smiling at his/her face $(56 \%)$, showing modesty and respect to the patient whatever his/her status (57\%),keeping the patient's secrets confidential (59\%), listening well to the patient's complaint and understanding his /her suffering (54\%), being patient, gentle and thoughtful with the patient (54\%), treating the patients fairly and objectively $(53 \%)$, without discrimination among them ,especially when examining the patient, the health practitioner should be kind, tender, and soft ,Especially when examining the patient, the health practitioner should be kind, tender, and soft (54\%) (Table 3). Our patients and our society deserve better.

\begin{tabular}{|c|c|c|c|c|c|c|c|c|}
\hline \multicolumn{9}{|c|}{ Table (3): The health practitioner's Ethics towards the patients: } \\
\hline \multirow{2}{*}{ Practices Statements } & \multicolumn{2}{|c|}{ Low } & \multicolumn{2}{|c|}{ Medium } & \multicolumn{2}{|c|}{ High } & \multirow{2}{*}{ mean } & \multirow{2}{*}{ Result } \\
\hline & Freq. & $\%$ & Fre. & $\%$ & F & $\%$ & & \\
\hline $\begin{array}{l}\text { Sincerity in work for Allah } \\
\text { Almighty- Your }\end{array}$ & 126 & $19.7 \%$ & 147 & $22.9 \%$ & 368 & $57.4 \%$ & 2.38 & High \\
\hline $\begin{array}{l}\text { To have the sense of watching } \\
\text { Allah Almighty in all } \\
\text { conditions }\end{array}$ & 113 & $17.6 \%$ & 124 & $19.3 \%$ & 404 & $63.0 \%$ & 2.45 & High \\
\hline $\begin{array}{l}\text { To have the sense that Allah } \\
\text { will ask him/her about all } \\
\text { deeds whether great or minor }\end{array}$ & 121 & $18.9 \%$ & 126 & $19.7 \%$ & 394 & $61.5 \%$ & 2.43 & High \\
\hline $\begin{array}{l}\text { Avoiding trivial things that } \\
\text { spoil man's work. }\end{array}$ & 173 & $27.0 \%$ & 131 & $20.4 \%$ & 337 & $52.6 \%$ & 2.26 & Medium \\
\hline $\begin{array}{l}\text { Accustoming oneself to be } \\
\text { satisfied. }\end{array}$ & 162 & $25.3 \%$ & 149 & $23.2 \%$ & 330 & $51.5 \%$ & 2.26 & Medium \\
\hline
\end{tabular}




\begin{tabular}{|c|c|c|c|c|c|c|c|c|}
\hline \multirow{2}{*}{ 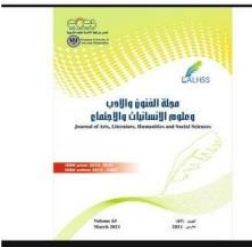 } & \multicolumn{6}{|c|}{ 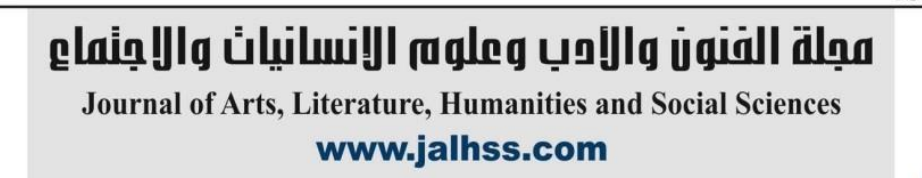 } & & \\
\hline & Jur & 021 & & يو 2021 & (68) & & & \\
\hline $\begin{array}{l}\text { Protecting oneself from } \\
\text { probable dangers while } \\
\text { practicing his/her profession. }\end{array}$ & 163 & $25.4 \%$ & 127 & $19.8 \%$ & 351 & $54.8 \%$ & 2.29 & Medium \\
\hline
\end{tabular}

\section{8) The health practitioner's Ethics towards the patients:}

The table 4 shows that $50 \%$ of the student has some high practices and medium practices for items of practitioner of health ethics toward themselves. A medium response was obtained from our responders with respect to well-reception of the patient and smiling at his/her face $(56 \%)$, treating the patients fairly and objectively (53\%), being patient, gentle and thoughtful with the patient $(54 \%)$, keeping the patient's secrets confidential (59\%),listening well to the patient's complaint and understanding his /her suffering (54\%), showing modesty and respect to the patient whatever his/her status (57\%), without discrimination among them ,especially when examining the patient, the health practitioner should be kind, tender, and soft ,Especially when examining the patient, the health practitioner should be kind, tender, and soft $(54 \%)$ (Table 4$)$.

\section{Table (4): The health practitioner`s Ethics towards the patients:}

\begin{tabular}{|c|c|c|c|c|c|c|c|c|}
\hline \multirow[t]{2}{*}{ Practice statements } & \multicolumn{2}{|c|}{ Low } & \multicolumn{2}{|c|}{ Medium } & \multicolumn{2}{|c|}{ High } & \multirow[t]{2}{*}{ mean } & \multirow[t]{2}{*}{ Result } \\
\hline & Freq. & $\%$ & Freq. & $\%$ & Freq. & $\%$ & & \\
\hline $\begin{array}{l}\text { Well-reception of the patient and smiling at his/her } \\
\text { face. }\end{array}$ & 191 & $29.8 \%$ & 89 & $13.9 \%$ & 361 & $56.3 \%$ & 2.27 & Medium \\
\hline $\begin{array}{l}\text { Listening well to the patient's complaint and } \\
\text { understanding his /her suffering. }\end{array}$ & 206 & $32.1 \%$ & 89 & $13.9 \%$ & 346 & $54.0 \%$ & 2.22 & Medium \\
\hline $\begin{array}{l}\text { Showing modesty and respect to the patient } \\
\text { whatever his/her status is. }\end{array}$ & 191 & $29.8 \%$ & 84 & $13.1 \%$ & 366 & $57.1 \%$ & 2.27 & Medium \\
\hline $\begin{array}{l}\text { Keeping the patient's secrets confidential (except } \\
\text { for necessity or a requiring need ) }\end{array}$ & 195 & $30.4 \%$ & 68 & $10.6 \%$ & 378 & $59.0 \%$ & 2.29 & Medium \\
\hline $\begin{array}{l}\text { Being patient, gentle and thoughtful with the } \\
\text { patient }\end{array}$ & 204 & $31.8 \%$ & 103 & $16.1 \%$ & 334 & $52.1 \%$ & 2.20 & Medium \\
\hline $\begin{array}{l}\text { Especially when examining the patient, the health } \\
\text { practitioner should be kind, tender, and soft. }\end{array}$ & 204 & $31.8 \%$ & 82 & $12.8 \%$ & 355 & $55.4 \%$ & 2.24 & Medium \\
\hline $\begin{array}{l}\text { Treating the patients fairly and objectively, } \\
\text { without discrimination among them }\end{array}$ & 211 & $32.9 \%$ & 89 & $13.9 \%$ & 341 & $53.2 \%$ & 2.20 & Medium \\
\hline $\begin{array}{l}\text { Being aware of committing any legitimate } \\
\text { violations (such as uncovering naked parts of the } \\
\text { patient's body, or being alone with the opposite } \\
\text { sex). these ethics }\end{array}$ & 211 & $32.9 \%$ & 69 & $10.8 \%$ & 361 & $56.3 \%$ & 2.23 & Medium \\
\hline $\begin{array}{l}\text { Confining the medical treatment of the patient to } \\
\text { what his/her condition requires only. }\end{array}$ & 249 & $38.8 \%$ & 115 & $17.9 \%$ & 277 & $43.2 \%$ & 2.04 & Medium \\
\hline $\begin{array}{l}\text { Being faithful and honest when telling the patient } \\
\text { (or the person representing him/her) about the } \\
\text { patient's condition. }\end{array}$ & 248 & $38.7 \%$ & 88 & $13.7 \%$ & 305 & $47.6 \%$ & 2.09 & Medium \\
\hline $\begin{array}{l}\text { Educating the patient about his condition and how } \\
\text { to maintain his/her health. }\end{array}$ & 224 & $34.9 \%$ & 89 & $13.9 \%$ & 328 & $51.2 \%$ & 2.16 & Medium \\
\hline $\begin{array}{l}\text { Never delaying referring the patient to another } \\
\text { person or place that helps in making his/her state } \\
\text { better. }\end{array}$ & 250 & $39.0 \%$ & 80 & $12.5 \%$ & 311 & $48.5 \%$ & 2.10 & Medium \\
\hline $\begin{array}{l}\text { Continuing to provide appropriate care and } \\
\text { treatment to the patient. }\end{array}$ & 233 & $36.3 \%$ & 77 & $12.0 \%$ & 331 & $51.6 \%$ & 2.15 & Medium \\
\hline Providing the patient with the information he/she & 234 & $36.5 \%$ & 93 & $14.5 \%$ & 314 & $49.0 \%$ & 2.12 & Medium \\
\hline
\end{tabular}




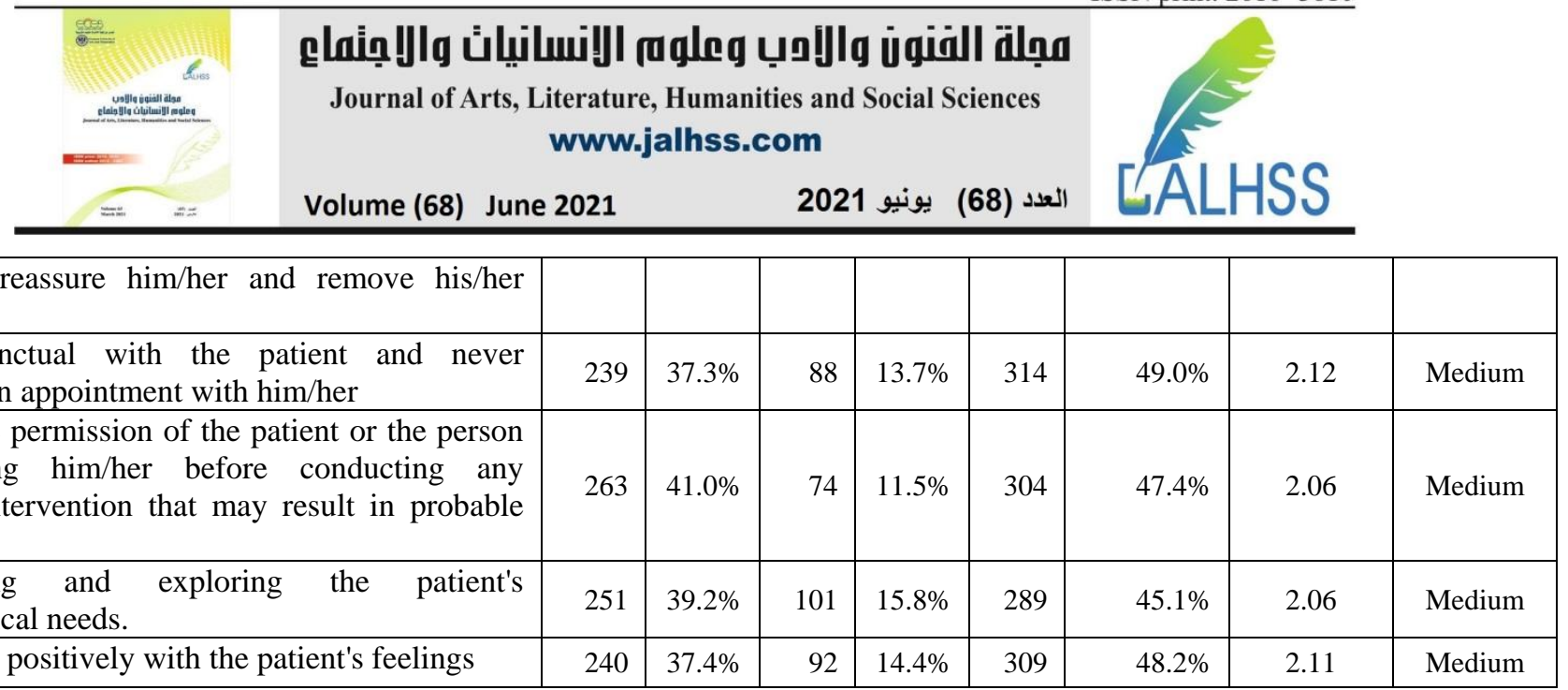

\section{9) The health practitioner`s Ethics towards the Profession:}

The table shows that the practices of student for ethics towards the patient's items all are medium $100 \%$. The health practitioner`s ethics towards his profession was evaluated as depicted in table 5.A medium response was obtained from our responders with respect to keeping the honor and reputation of their profession (52\%) whereas a high response was obtained for sticking to the most possible perfection and competency in practicing the profession (80\%).A medium response was obtained for practitioner ethics with respect for developing the profession scientifically and practically (47\%),following up on new developments in his/her area of specialty $(46.6 \%)$, commitment to professional standards and general ethics while practicing professional and other activities $(52.7 \%)$.

Table (5): The health practitioner`s Ethics towards the Profession:

\begin{tabular}{|l|r|r|r|r|r|r|r|l|}
\hline \multirow{2}{*}{ Practice statements } & \multicolumn{2}{|c|}{ Low } & \multicolumn{2}{|c|}{ Medium } & \multicolumn{2}{|c|}{ High } & mean & Result \\
\cline { 2 - 9 } & Freq. & $\%$ & Freq. & $\%$ & Freq. & $\%$ & & Medium \\
\hline $\begin{array}{l}\text { Keeping the honor and reputation } \\
\text { of the profession }\end{array}$ & 218 & $34.0 \%$ & 69 & $10.8 \%$ & 354 & $55.2 \%$ & 2.21 & \\
\hline $\begin{array}{l}\text { Sticking to the most possible } \\
\text { perfection and competency in } \\
\text { practicing the profession }\end{array}$ & 30 & $4.7 \%$ & 97 & $15.1 \%$ & 514 & $80.2 \%$ & 2.76 & High \\
\hline $\begin{array}{l}\text { Developing the profession, } \\
\text { scientifically and practically. }\end{array}$ & 211 & $32.9 \%$ & 125 & $19.5 \%$ & 305 & $47.6 \%$ & 2.15 & Medium \\
\hline $\begin{array}{l}\text { Following up on new } \\
\text { developments in his/her area of } \\
\text { specialty. }\end{array}$ & 205 & $32.0 \%$ & 137 & $21.4 \%$ & 299 & $46.6 \%$ & 2.15 & Medium \\
\hline $\begin{array}{l}\text { Commitment to professional } \\
\text { standards and general ethics while } \\
\text { practicing professional and other } \\
\text { activities. }\end{array}$ & 208 & $32.4 \%$ & 95 & $14.8 \%$ & 338 & $52.7 \%$ & 2.20 & Medium \\
\hline $\begin{array}{l}\text { Sticking to the special regulations } \\
\text { governing his/her profession. }\end{array}$ & 210 & $32.8 \%$ & 93 & $14.5 \%$ & 338 & $52.7 \%$ & 2.20 & Medium \\
\hline $\begin{array}{l}\text { Asking for help in solving the } \\
\text { problems that negatively affect } \\
\text { the service he/she offers, } \\
\text { whenever necessary. }\end{array}$ & 228 & $35.6 \%$ & 108 & $16.8 \%$ & 305 & $47.6 \%$ & 2.12 & \\
\hline $\begin{array}{l}\text { A Voiding the quest for } \\
\text { reputation at the expense of the }\end{array}$ & 257 & $40.1 \%$ & 92 & $14.4 \%$ & 292 & $45.6 \%$ & 2.05 & Medium \\
\hline
\end{tabular}




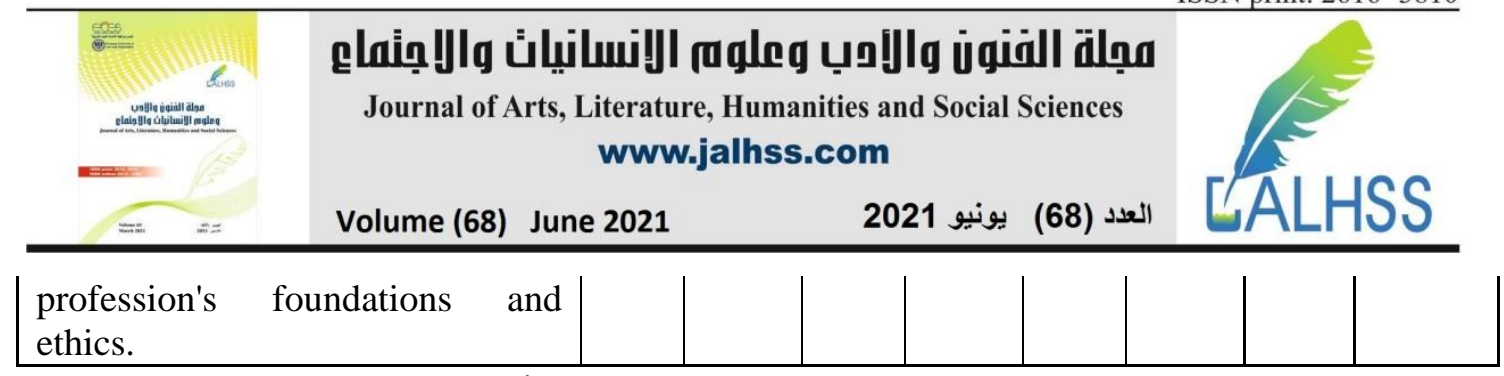

10) The health practitioner`s Ethics towards the his /her colleagues:

The table shows that the practices of student towards the Profession items all is medium $100 \%$.In our study the health practitioner's ethics towards his /her colleagues was evaluated by 641 subjects as depicted in table 6 and it was revealed that the practices of student for ethics towards the colleagues items was medium. A medium response $(51.8 \%)$ was obtained from our responders with respect to establishing a relationship with colleagues on mutual trust and positive cooperation for the benefit of patients however a high response (65.8\%) was obtained with respect to adopting good behavior with his/her colleagues and treating them as he/she likes them to treat him/her (Table 6) Similarly a medium response was reported with respect to adherence to accuracy and honesty in evaluating the performance of those who work with him/her and a medium response was reported with respect to ethics adherence to Shari'a rules when dealing with colleagues (eg avoiding being alone with foreign women) (Table 6).

Table (6): The health practitioner`s Ethics towards the his /her colleagues:

\begin{tabular}{|c|c|c|c|c|c|c|c|c|}
\hline \multirow[t]{2}{*}{ Practice statements } & \multicolumn{2}{|c|}{ Low } & \multicolumn{2}{|c|}{ Medium } & \multicolumn{2}{|c|}{ High } & \multirow[t]{2}{*}{ mean } & \multirow[t]{2}{*}{ Result } \\
\hline & Freq. & $\%$ & Freq. & $\%$ & Freq. & $\%$ & & \\
\hline $\begin{array}{l}\text { Establishing a relationship with } \\
\text { colleagues on mutual trust and } \\
\text { positive cooperation for the benefit } \\
\text { of patients. }\end{array}$ & 202 & $31.5 \%$ & 107 & $16.7 \%$ & 332 & $51.8 \%$ & 2.20 & Medium \\
\hline $\begin{array}{l}\text { Adopting good behavior with } \\
\text { his/her colleagues and treating them } \\
\text { as he/she likes them to treat } \\
\text { him/her. }\end{array}$ & 71 & $11.1 \%$ & 148 & $23.1 \%$ & 422 & $65.8 \%$ & 2.55 & High \\
\hline $\begin{array}{l}\text { Avoiding the dishonest behavior } \\
\text { when dealing with other colleagues. }\end{array}$ & 175 & $27.3 \%$ & 76 & $11.9 \%$ & 390 & $60.8 \%$ & 2.34 & Medium \\
\hline $\begin{array}{l}\text { Avoiding the direct criticism of the } \\
\text { colleague or underestimating } \\
\text { his/her efforts with the patient. }\end{array}$ & 197 & $30.7 \%$ & 88 & $13.7 \%$ & 356 & $55.5 \%$ & 2.25 & Medium \\
\hline $\begin{array}{l}\text { Transferring his/her experience and } \\
\text { skills to his/her colleagues, } \\
\text { particularly those who are still in } \\
\text { the training stage. }\end{array}$ & 221 & $34.5 \%$ & 102 & $15.9 \%$ & 318 & $49.6 \%$ & 2.15 & Medium \\
\hline $\begin{array}{l}\text { Adherence to accuracy and honesty } \\
\text { in evaluating the performance of } \\
\text { those who work with him/her or } \\
\text { those who are still in the training } \\
\text { stage. these ethics }\end{array}$ & 248 & $38.7 \%$ & 84 & $13.1 \%$ & 309 & $48.2 \%$ & 2.10 & Medium \\
\hline $\begin{array}{l}\text { Adherence to Shari'a rules when } \\
\text { dealing with colleagues (eg } \\
\text { avoiding being alone with foreign } \\
\text { women(. }\end{array}$ & 214 & $33.4 \%$ & 88 & $13.7 \%$ & 339 & $52.9 \%$ & 2.20 & Medium \\
\hline
\end{tabular}

The health practitioner's ethics towards his/her institutions as depicted in table 7 . It was revealed that the practices of student for ethics towards their institutions reported to be medium .A high response $(73.5 \%)$ was obtained from our responders with 


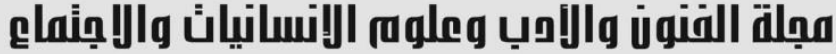 \\ Journal of Arts, Literature, Humanities and Social Sciences www.jalhss.com \\ Volume (68) June 2021 \\ العدد (68) يونيو 2021

respect to regulations, sticking to the laws and instructions of the institution he/she works in whereas a medium response $(50 \%)$ was obtained towards the adherence to accuracy and honesty when issuing any reports, certificates or documents or when dealing with the files of patients in the institution he/she works in. . Above medium response $(54 \%)$ was obtained with respect to preserving the institution's properties and using them well. (Table 7).

Table (7): The health practitioner`s Ethics towards his/her institutions:

\begin{tabular}{|l|r|r|r|r|r|r|l|l|}
\hline \multicolumn{1}{|c|}{ Practice statements } & \multicolumn{2}{|c|}{ Low } & \multicolumn{2}{c|}{ Medium } & \multicolumn{2}{c|}{ High } & mean & Result \\
\cline { 2 - 9 } & Freq. & $\%$ & Freq. & $\%$ & Freq. & $\%$ & & Medium \\
\hline $\begin{array}{l}\text { Keeping the reputation of the } \\
\text { institution he/she works in. }\end{array}$ & 205 & $32.0 \%$ & 108 & $16.8 \%$ & 328 & $51.2 \%$ & 2.19 & \\
\hline $\begin{array}{l}\text { Effective contribution to } \\
\text { developing and promoting the } \\
\text { institution he/she works in. }\end{array}$ & 233 & $36.3 \%$ & 117 & $18.3 \%$ & 291 & $45.4 \%$ & 2.09 & Medium \\
\hline $\begin{array}{l}\text { Preserving the institution's } \\
\text { properties and using them well. }\end{array}$ & 198 & $30.9 \%$ & 94 & $14.7 \%$ & 349 & $54.4 \%$ & 2.24 & Medium \\
\hline $\begin{array}{l}\text { Sticking to the laws, regulations } \\
\text { and instructions of the institution } \\
\text { he/she works in. }\end{array}$ & 44 & $6.9 \%$ & 126 & $19.7 \%$ & 471 & $73.5 \%$ & 2.67 & High \\
\hline $\begin{array}{l}\text { Adherence to accuracy and } \\
\text { honesty following scientific and } \\
\text { administrative principles) when } \\
\text { issuing any reports, certificates or } \\
\text { documents or when dealing with } \\
\text { the files of patients in the } \\
\text { institution he/she works in. }\end{array}$ & 230 & $35.9 \%$ & 90 & $14.0 \%$ & 321 & $50.1 \%$ & 2.14 & \\
\hline
\end{tabular}

The health practitioner`s ethics towards his/her society was evaluated and the results are depicted in table 8. It was revealed that the health practitioner's ethics towards his/her society was reported to be medium. A medium response $(56 \%)$ was obtained from our responders with respect to be as a good model for others in his morals, reputation, speech, and acts towards our society. Similarly a medium response (48\%) was obtained from our responders with respect to educating the community on the proper methods of dealing with environmental and social pathogens.

\begin{tabular}{|c|c|c|c|c|c|c|c|c|}
\hline \multicolumn{9}{|c|}{ Table (8): The health practitioner's Ethics towards his/her society: } \\
\hline \multirow[t]{2}{*}{ Practice statements } & \multicolumn{2}{|c|}{ Low } & \multicolumn{2}{|c|}{ Medium } & \multicolumn{2}{|c|}{ High } & \multirow[t]{2}{*}{ mean } & \multirow[t]{2}{*}{ Result } \\
\hline & Freq. & $\%$ & Freq. & $\%$ & Freq. & $\%$ & & \\
\hline $\begin{array}{l}\text { To be a good model for others (in } \\
\text { his/her morals, reputation, speech, } \\
\text { and acts) }\end{array}$ & 172 & $26.8 \%$ & 109 & $17.0 \%$ & 360 & $56.2 \%$ & 2.29 & Medium \\
\hline $\begin{array}{l}\text { Educating the community on the } \\
\text { proper methods of dealing with } \\
\text { environmental and social } \\
\text { pathogens. }\end{array}$ & 182 & $28.4 \%$ & 125 & $19.5 \%$ & 334 & $52.1 \%$ & 2.24 & Medium \\
\hline $\begin{array}{l}\text { Improving the standards and } \\
\text { quality of health services offered }\end{array}$ & 231 & $36.0 \%$ & 113 & $17.6 \%$ & 297 & $46.3 \%$ & 2.10 & Medium \\
\hline
\end{tabular}




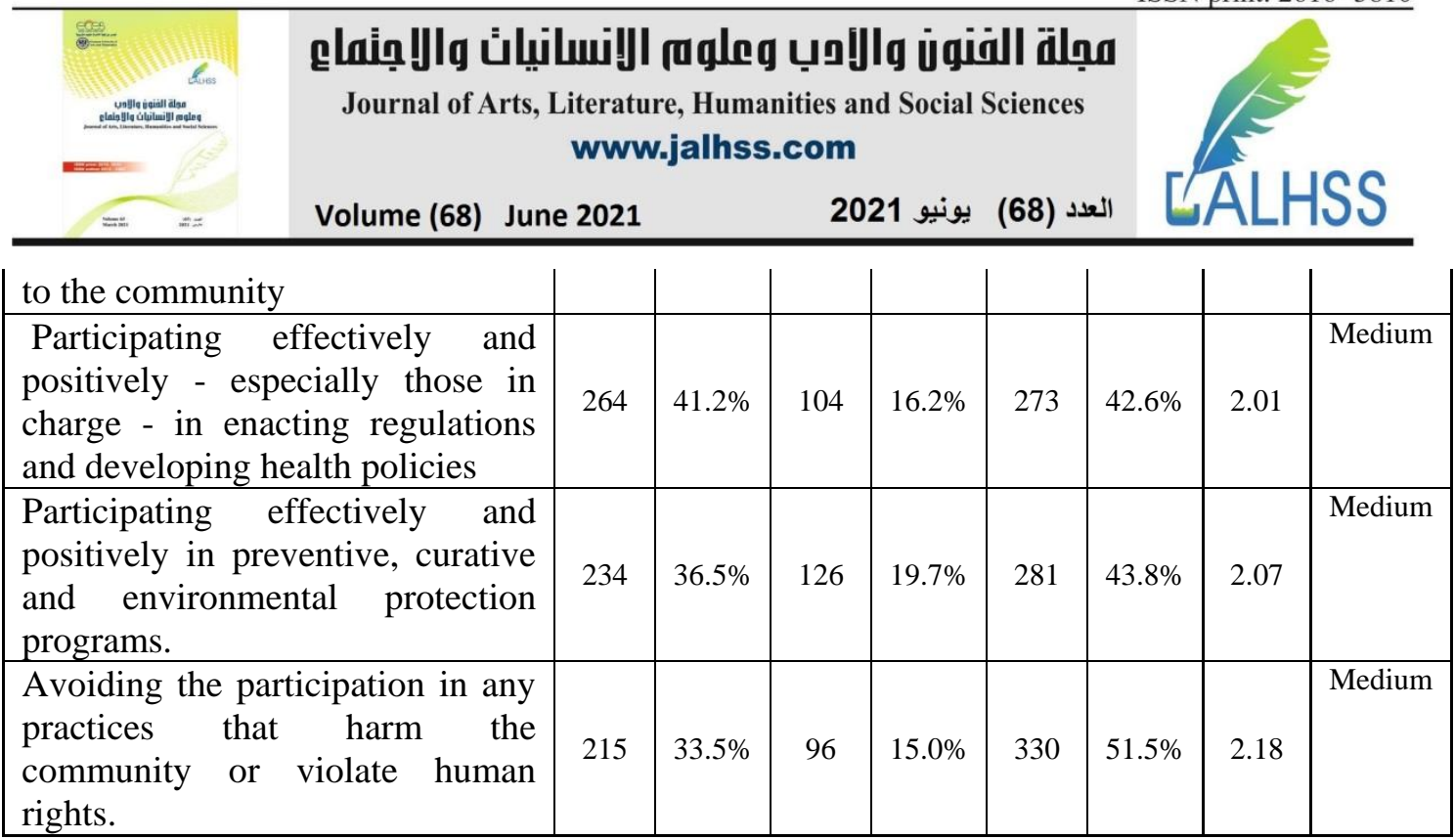

The health practitioner`s ethics towards different variable has been determined by our undergraduate responders .A high value $(56.8 \%)$ of ethics of healthcare practitioners was reported towards himself/herself .Rest of the variables has shown a medium value of health practitioner`s ethics with respect health practitioner's ethics towards the patients, towards his Profession, towards his /her colleagues, towards his/her institutions , towards his/her society (Table 9)

\begin{tabular}{|l|c|c|c|c|c|c|c|c|}
\hline \multicolumn{7}{|c|}{ Table (9):The health practitioner`s Ethics towards different variable } \\
\cline { 2 - 10 } Practice statements & \multicolumn{2}{|c|}{ Low } & \multicolumn{2}{c|}{ Medium } & \multicolumn{2}{c|}{ High } & mean & Result \\
\cline { 2 - 10 } & Freq. & $\%$ & Freq. & $\%$ & Freq. & $\%$ & & High \\
\hline $\begin{array}{l}\text { The health practitioners } \\
\text { himself/herself towards }\end{array}$ & 148 & $23.1 \%$ & 129 & $20.1 \%$ & 364 & $56.8 \%$ & 2.36 & Medium \\
$\begin{array}{l}\text { The health practitioner`s } \\
\text { Ethics towards the patients }\end{array}$ & 214 & $33.4 \%$ & 100 & $15.6 \%$ & 327 & $51.0 \%$ & 2.18 & Medium \\
\hline $\begin{array}{l}\text { The health practitioners } \\
\text { Ethics towards the } \\
\text { Profession }\end{array}$ & 190 & $29.6 \%$ & 123 & $19.2 \%$ & 328 & $51.2 \%$ & 2.22 & Medium \\
\hline $\begin{array}{l}\text { The health practitioner`s } \\
\text { Ethics towards the his /her } \\
\text { colleagues }\end{array}$ & 178 & $27.8 \%$ & 126 & $19.7 \%$ & 337 & $52.6 \%$ & 2.25 & Medium \\
$\begin{array}{l}\text { The health practitioner`s } \\
\text { Ethics towards his/her } \\
\text { institutions }\end{array}$ & 197 & $30.7 \%$ & 111 & $17.3 \%$ & 333 & $52.0 \%$ & 2.21 & \\
\hline $\begin{array}{l}\text { The health practitioner`s } \\
\text { Ethics towards his/her } \\
\text { society }\end{array}$ & 225 & $35.1 \%$ & 132 & $20.6 \%$ & 284 & $44.3 \%$ & 2.09 & Medium \\
\hline over all practice & 147 & $22.9 \%$ & 182 & $28.4 \%$ & 312 & $48.7 \%$ & 2.26 & Medium \\
\hline
\end{tabular}

\section{DISCUSSION:}

Ethics is the study of morality and systematic analysis of moral decisions and behaviors and practicing those decisions. Throughout the globe, Medical practice has become the commercialized, and ethics has taken a backseat. Recent advances and awareness in medical science have increased ethical issues related to Health care. The major objective of the ethics education is to enable students to learn and identify difficult situations and deal with them in a rational and principled manner. There has been a growing public awareness regarding the ethical conduct of healthcare 


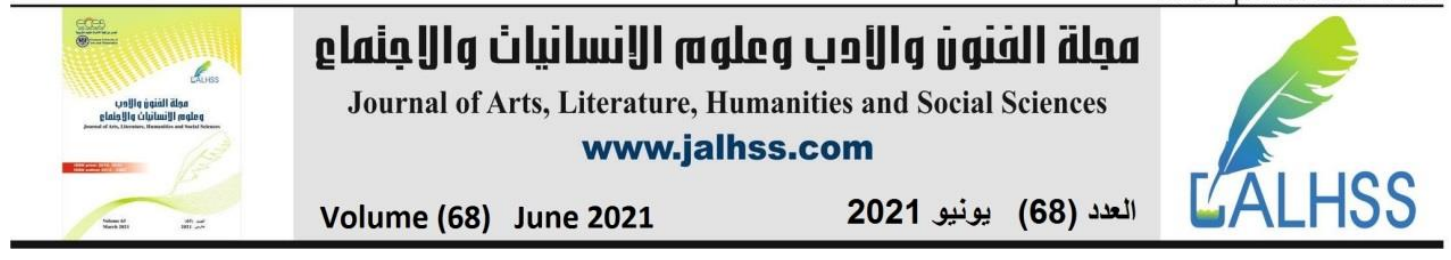

practitioners, and complaints against medical physicians appear to be escalating. This increase in litigation against doctors is issue of immediate concern. The training of the healthcare practitioners for medical ethics is regarded as a key element in determining the ethical and legal conduct within the healthcare sector. The purpose of this study is to assess the knowledge, attitudes and awareness about medical ethics among university under graduate students in relation to medical ethics and law. The results of our study will be a useful guide to teachers of medical students and curricula designers.

Majority of the students (58.5\%) mentioned that the source of their knowledge was from lectures/seminars/clinical discussions, while $20.7 \%$ derived the knowledge from mass media and $(8.6 \%)$ derived the knowledge from literature and medical journals as well (Figure 3) Similar results were achieved by the study by Ramesh Acharya and colleagues (23) source of knowledge for students was (35.7\%) from lectures/seminars, $(24.5 \%)$ on the job, $(21.4 \%)$ training and $(17.3 \%)$ own reading while Chatterjee B and Sarkar J (24) observed that 54.7\% students gained knowledge from classroom lectures and $47.8 \%$ from books. In a study by Tahir S and colleagues (25), a high percentage (36\%) had never heard of bioethics.These findings are similar to that in previously completed studies in Medical students at a New Mexico school reported that study participants preferred clinical and expert-oriented learning like case conferences, and workshops involving a multidisciplinary approach over the traditional didactic approach which was also shown as significantly [p < 0.0001] effective a study by L W Roberts (26) in 2004.

Only $15.4 \%$ of the students were aware of the existence of the institutional ethics committee and many of them did not know its specific functions. This highlights the need for the administrative section of teaching hospitals to publicize their work at regular intervals for the benefit of trainees. The institutional ethics committee should publish data concerning to its involvement in different health-related activities within the university colleges and these should be announced, circulated in all colleges and the students as well. The institutional ethics committee should publish data concerning to its involvement in different health-related activities within the university colleges and these should be announced, circulated in all colleges and the students as well. Several studies findings emphasize the importance of continuing ethics education throughout the undergraduate, graduate periods. It has been reported that the situation does not appear to improve once medical education is completed, and it may even worsen as trainee's progress through education (27). Patenaude and others (28) conducted a three-year cohort study at the University of Sherbrooke Medical School in Quebec, Canada, found that students' understanding of ethics did not improve substantially with education. About $72 \%$ of the students participated remained at the same stage of moral reasoning in their third year of study as in their first, as evidenced by mean scores of 3.46 in the first year and 3.48 in the third year. In fact $15 \%$ moved to the higher stage whereas $13 \%$ moved down to the lower stage. All the above findings of this study emphasize the importance of continuing ethics education throughout the undergraduate, internship periods. Registered professional 


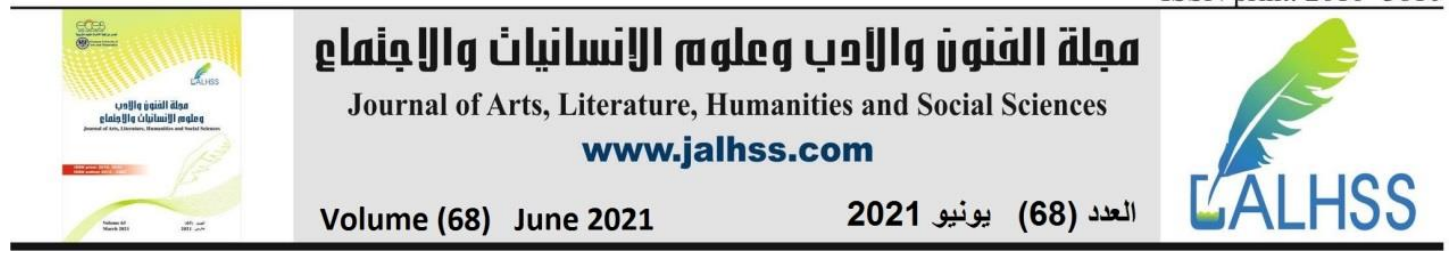

organizations should provide detailed guidelines on medical ethics in their journals, to prepare future generations of medical professionals for ethically sound practice.

The health practitioner`s ethics towards himself/herself

Personal and professional values of healthcare practitioners influence their clinical decisions. Understanding these values for individuals and across healthcare professions can help improve patient-centered decision-making by individual practitioners and interprofessional teams, respectively. (29) In our study the health practitioner`s ethics towards himself /herself was evaluated by our responders and it was reported that a high value of healthcare practitioners ethics towards himself/herself was reported (Table 3).A high response was obtained from our responders with respect of having sense of watching Allah Almighty in all conditions $(63.0 \%)$ and having the sense that Allah will ask himself/herself about all deeds whether great or minor $(61 \%)$ as well as having sincerity in work for Allah Almighty $(57.4 \%)$ however a medium response was obtained from our undergraduates with respect of protecting oneself from probable dangers while practicing himself/herself profession. (Table 3).Medical ethics can be utilized by the healthcare professionals to solve any confusion or conflict during clinical decisions. These values include the respect for autonomy, non-maleficence, beneficence, and justice. (31) Such tenets may allow doctors, care providers, and families to create a treatment plan and work towards the same common goal. (32) It is important to note that these four values are not ranked in order of importance or relevance and that they all encompass values pertaining to medical ethics. (33) With support from the American Academy of Arts and Sciences, the Robert Wood Johnson Foundation, and the Kellogg Foundation, first surveyed more than 100 healthcare leaders worldwide about their sense of need for a shared code of ethics and received overwhelming encouragement.(34)

\section{A- The health practitioner's Ethics towards the patients:}

While evaluating the health practitioner`s ethics towards their patients, a medium value of ethics towards the patients was reported (Table 4). A medium response was obtained from our responders with respect to well-reception of the patient and smiling at his/her face $(56 \%)$, listening well to the patient's complaint and understanding his /her suffering (54\%), showing modesty and respect to the patient whatever his/her status (57\%), being patient, gentle and thoughtful with the patient (54\%) ,keeping the patient's secrets confidential (59\%),treating the patients fairly and objectively $(53 \%)$, without discrimination among them ,especially when examining the patient, the health practitioner should be kind, tender, and soft ,Especially when examining the patient, the health practitioner should be kind, tender, and soft (54\%) (Table 4). Our patients and our society deserve better.

\section{B- The health practitioner's ethics towards his/her profession:}

We evaluated the health practitioner's ethics towards his profession and it was revealed that a medium value of ethics of healthcare practitioners towards his Profession (Table 5). The health practioner should be decent towards women and should not divulge the secrets of his patients. Healthcare professionals should speak well of his colleagues. Our health practitioner must refer to the policy as a challenge to their core ethical principles, explicitly patient confidentiality and trust, which 


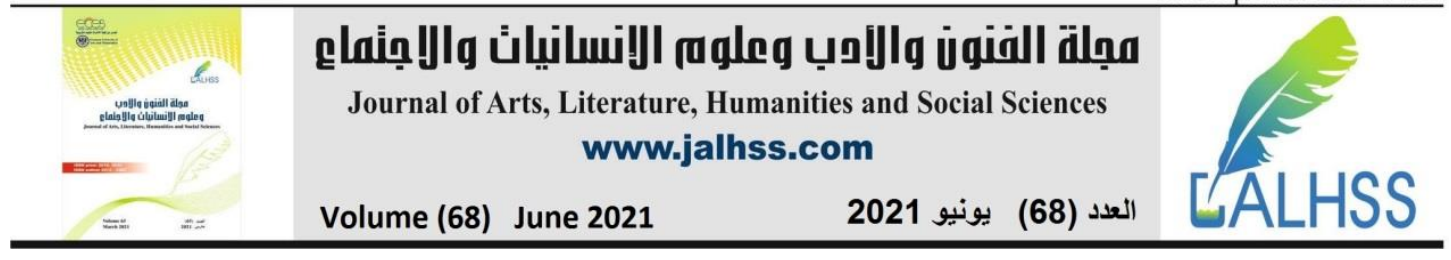

varied depending on their clinical specialty. If physicians claim to be the defenders of the "true calling" of medical care, nurses claim to defend care of the whole person, healthcare executives claim to be defenders of inevitably limited social resources, etc, unity of action may suffer and, worse, the dialogue may degrade into contentiousness and mistrust among the professionals. Professionalism can be sensibly taught in medical schools as long as open discussion are allowed to take place about different social factors .There is a growing interest in the ethics of the health practitioner's towards the Profession . (35) While evaluating the health practitioner ethics towards his profession, a medium response was obtained from our responders with respect to keeping the honor and reputation of the profession (52\%) whereas a high response was obtained for sticking to the most possible perfection and competency in practicing the profession $(80 \%)$.A medium response was obtained for practitioner ethics with respect for developing the profession scientifically and practically (47\%),following up on new developments in his/her area of specialty (46.6\%), commitment to professional standards and general ethics while practicing professional and other activities $(52.7 \%)$, avoiding the quest for reputation at the expense of the profession's foundations and ethics (45.6\%), asking for help in solving the problems that negatively affect the service he/she offers, whenever necessary $(47.6 \%)$.In health care system, social responsibility is the ethical obligation that requires hospitals as delivering quality health care to everyone who is entitled to it like to care for sick and ill people is a social obligation that extends beyond the commercial realm. (36)

\section{C- The health practitioner's ethics towards the his /her colleagues:}

A physician must consider it as a privilege to deliver best service to his colleagues, friends and their immediate juniors or dependents. The code of medical ethics urges a healthcare profession or a physician to 'happily and cheerfully render his clinical and professional services to his physician-colleagues and their immediate family members without seeking any monetary compensation.' However, there are no guidelines or rule that a healthcare profession or physician might not charge another colleague for his services. $(37,38)$ When healthcare profession or physician is called from a distance to attend to, or advise, a colleague, he must be reimbursed for appraised travelling and other incidental expenses. (39) Unfortunately, many healthcare profession or physician who themselves require specialized help from their colleagues cheat on them by seeking free treatment for themselves, their families, children and also for friends and distant relatives. (40) This is not fair for the treating colleague or physician who is providing best treatment without receiving compensation for his precious time and efforts.(41) . (Table 6) A medium response (51.8\%) was obtained from our responders with respect to establishing a relationship with colleagues on mutual trust and positive cooperation for the benefit of patients however a high response $(65.8 \%)$ was obtained with respect to adopting good behavior with his/her colleagues and treating them as he/she likes them to treat him/her (Table 6) Similarly a medium response was reported from our undergraduates with respect to adherence to accuracy and honesty in evaluating the performance of those who work with him/her or those who are still in the training stage. Also a medium response was 


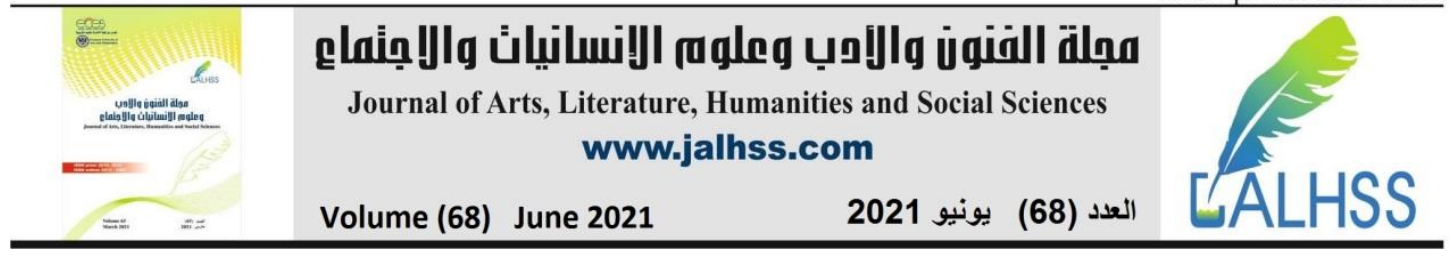

reported from our responders with respect to ethics adherence to Shari'a rules when dealing with colleagues (eg avoiding being alone with foreign women) (Table 6).

\section{D- The health practitioner`s ethics towards his/her institutions:}

In our study the health practitioner's ethics towards his/her institutions was evaluated by 641 undergraduate responders and it was reported that a medium value of ethics of healthcare practitioners towards his /her institutions was reported (Table 7).A high response $(73.5 \%)$ was obtained from our responders with respect to sticking to the laws, regulations and instructions of the institution he/she works in (Table 7). whereas a medium response $(50 \%)$ was obtained from our responders with respect to Adherence to accuracy and honesty (following scientific and administrative principles) when issuing any reports, certificates or documents or when dealing with the files of patients in the institution he/she works in. (Table 7). Above medium response $(54 \%)$ was obtained with respect to preserving the institution's properties and using them well. It is a health practitioner's responsibility to preserve his/her institutions properties. $(41,42)$

\section{E- The health practitioner`s ethics towards his/her society:}

With respect to ethics of health practitioner towards his/her society 's an overall medium response of was recorded by our responders (Table 8).A medium response $(56 \%)$ was obtained from our responders with respect to be as a good model for others in his morals, reputation, speech, and acts towards our society. Similarly a medium response $(48 \%)$ was obtained from our responders with respect to educating the community on the proper methods of dealing with environmental and social pathogens. (Table 8) Similarly a medium response (51\%) was obtained from our responders with respect to avoiding the participation in any practices that harm the community or violate human rights .However a low medium response (46\%) was obtained from our responders with respect to improving the standards and quality of health services offered to the community. Our finding was similar to the previous study done (43)

\section{F- The health practitioner's Ethics towards different variable:}

In our study the health practitioner's ethics towards different variable has been determined by our undergraduate responders (641) (Table 9) and it was reported that a high value $(56.8 \%)$ of ethics of healthcare practitioners towards himself/herself was reported however a medium value of health practitioner's ethics was reported with respect to other all variables like health practitioner's ethics towards the patients, towards his Profession, towards his /her colleagues, towards his/her institutions, towards his/her society (Table 9) While ownership of institutions or other organizations that deliver medical care may be appropriate, care itself cannot be owned and must be viewed as a service that is rendered and remunerated under the stewardship of those in the healthcare system, rather than merely sold to individuals or communities .This Code of Ethics provides that any level of advertising must not contain false, inaccurate, misleading or incomplete information either on the services provided or on the individual professional status and neither should it be selfpromotional.(44) In our study the health practitioner`s ethics towards patients, 


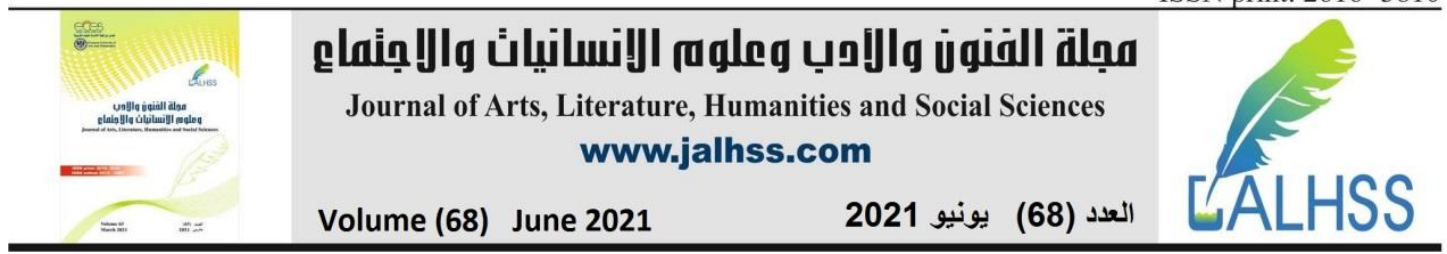

society, institutions, colleagues, Profession was reported to be medium except for himself reported to be high.

It was indicated that the attitude of the health practitioner medical ethics towards himself/herself was reported to be having highest values however a medium value of health practitioner`s ethics was reported towards the patients, towards his profession, towards his /her colleagues, towards his/her institutions, towards his/her society .Overall it was satisfactory though many students were deficient of knowledge regards to four basic principles. The undergraduate student's attained knowledge of medical ethics derived ethics knowledge from lectures /seminars /clinical discussions, It is important to gather baseline information on ethics awareness from different batches of students to guide the evaluation of the current ethics curriculum along with its teaching methodology in our university colleges.

\section{Conclusions:}

It was concluded that majority of the students $(58.5 \%)$ mentioned that the source of their knowledge was from lectures/seminars/clinical discussions, while $20.7 \%$ derived the knowledge from mass media and $(8.6 \%)$ derived the knowledge from literature and medical journals as well .The high value of ethics of healthcare practitioners towards himself was reported however a medium value was reported towards his patients, his profession, his colleagues, his institution and towards his society.There is a pressing need to implement the ethics education in all colleges in the University of Tabuk to understand moral principles and analyze and define their own values.

\section{ACKNOWLEDEGMENTS}

The authors would like to acknowledge the financial support for this work from the Deanship of Scientific Research, University of Tabuk, Saudi Arabia. Grant No. S1440-0298.

\section{REFERENCES}

1. Beauchamp TL and Childress JF. Principles of Biomedical ethics. $7^{\text {th }}$ Ed. Oxford: Oxford University Press. 2013

2. Gillon R. Medical ethics: four principles plus attention to scope. BMJ 1994; 309:184-188

3. Goldie J. Review of ethics curricula in undergraduate medical education. Med Educ. 2000;34:108-19.

4. Anup N, Himanshu K, Gautam B, Sonia P, Swasti T: Knowledge, attitude \& practices regarding Ethics \& Law amongst medical and dental professionals in Rajasthan ĐA. Questionnaire study. IOSR Journal of Dental and Medical Sciences (IOSR-JDMS) May 2014, 13(5):102 \pm 109.

5. Nazish I, Imran I, Masood J, Nauman M: Health ethics education: knowledge, attitudes and practice of healthcare ethics among interns and residents in Pakistan. JPMI 2014, 28(4):383 \pm 389 .

6. Thomas A, David G: Biomedical Ethics 4th edition,; 1996. 


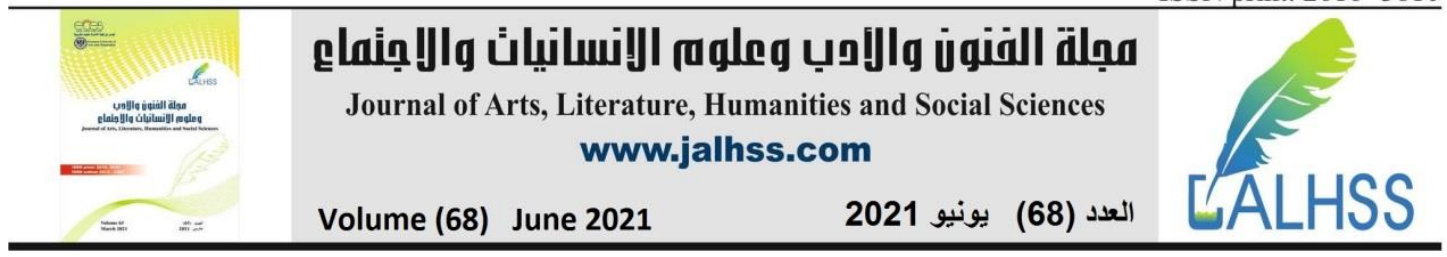

7. Australian Medical Council: Good Medical Practice: A Code of Conduct for Doctors in Australia. July 2009.

8. Shukr I, Roff S. Prevalence of lapses in academic integrity in two Pakistani medical colleges. Med Teach 2015;37:470-5.

9. Villanueva LA, Collado Pena S. [Attitudes and hierarchy of medical values in a gynecology and obstetrics department]. Ginecol Obstet Mex 2004;72:273-8.

10. Baker DM, Lee MJ, Folan AM, Blackwell S, Robinson K, Wootton R, Sebastian S,Brown SR, Jones GL, Lobo AJ. Development and evaluation of a patient decision aid for patients considering ongoing medical or surgical treatment options for ulcerative colitis using a mixed-methods approach: protocol for discuss study. BMJ Open. 2020 Jan 14;10(1):

11. Stern DT. A framework for measuring professionalism. Measuring medical professionalism 2006:3-14.

12. Tavaokkoli SN, Nejadsarvari N, Ebrahimi A. Analysis of medical confidentiality from the islamic ethics perspective. J Relig Health. 2015 Apr; 54(2):427-34.

13. Forouzadeh M, Kiani M, Bazmi S. Professionalism and its role in the formation of medical professional identity. Med J Islam Repub Iran. 2018 Dec 26;32:130.

14. El-SobkeySalwa B, AlmoajelAlyah M, Al-Muammar May N. Knowledge and attitude of Saudi health profession students regarding patient's bill of rights. Int J Health Policy Manag. 2014;3(3):117-22.

15. Medical Malpractice: Unethical Medical Treatment [https://www.avvo.com/legal-guides/ugc/ medical malpractice-unethical-medicaltreatment]

16. Brian P Hanley, William Bains, George Church Review of Scientific SelfExperimentation: Ethics History, Regulation, Scenarios, and Views Among Ethics Committees and Prominent Scientists . Rejuvenation Res . 2019 Feb;22(1):31-42.

17. Mays VM. Methods for Increasing Recruitment and Retention of Ethnic Minorities in Health Research Through Addressing Ethical Concerns. Seventh Conf Health Survey Res Methods (1999). 2001 Feb;2001:97-99.

18. Reddy C: Medical Ethics. Indian Journal of Dent Res August 13, 2009, 18(2):47.

19. Satyamev J: Aamir Khan Hurts Doctors; IMA Demands Apology, International Business Times Press,2012. Available from: http://www.ibtimes.co.in/articles/349644/20120607/satyamev-jayateaamirkhandoctors-tv-talk.htm.

20. Patenaude J, Niyonsenga T, Fafard D. Changes in students' moral development during medical school: a cohort study. CMAJ. 2003 Apr1;168(7):840-4.

21. Lwanga SK, Lemeshow S. Sample size determination in health studies: A practical manual. Geneva: World Health Organization. 1991

22. Chatterjee B and Sarkar J. Awareness of medical ethics among undergraduates in a West Bengal medical college. Indian Journal of Medical Ethics 2012; 9(2): 93-100.

23. Acharya RP and Shakya YL. Knowledge, attitude and practice of medical ethics among medical intern students in a Medical College in Kathmandu. Bangladesh Journal of Bioethics 2015; 6(3). 


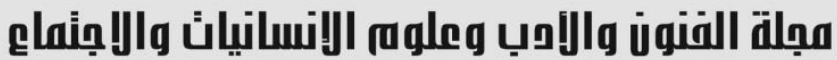 \\ Journal of Arts, Literature, Humanities and Social Sciences www.jalhss.com \\ Volume (68) June 2021 \\ العدد (68) يونيو 2021}

24. Chatterjee B and Sarkar J. Awareness of medical ethics among undergraduates in a West Bengal medical college. Indian Journal of Medical Ethics 2012; 9(2): 93-100. 25. Tahir S, Ghafoor F, Ayub R, Zaidi A and Khan AU. Perception of ethical issues, encountered in undergraduate medical and dental education. Medical \& Dental Education 2012; 32(2): 322-325.

26. Roberts LW, Green Hammond KA, Geppert GM, Warner TD. The positive role of professionalism and ethics training in medical education: a comparison of medical student and resident perspectives. Acad Psychiatry. 2004 Fall; 28(3):170-82.

27. Feudtner C, Christakis DA. Ethics in a short white coat: the ethical dilemmas that medical students confront. Acad Med. 1993 Apr; 68(4):249-54

28. Patenaude J, Niyonsenga T, Fafard D. Changes in students' moral development during medical school: a cohort study. CMAJ. 2003 Apr1;168(7):840-4.

29. Brodrick M. J Med Philos. Bioethics and the Rule of Law: A Classical Liberal Theory. 2020 May 21

30. Getz LJ, Dellaire G. Sci Eng Ethics. Back to Basics: Application of the Principles of Bioethics to Heritable Genome Interventions. 2020 Jun 10.

31. Weise, Mary. "Medical Ethics Made Easy". Professional Case Management. 2016. 21 (2): 88-94

32. Bioethic Tools: Principles of Bioethics". depts.washington.edu. Archived from the original on 2017-05-10. Retrieved 2017-03-21.

33. Mueller PS. Teaching and assessing professionalism in medical learners and practicing physicians. Rambam Maimonides Med J 2015;6:e0011.

34. Shiriki K Kumanyika .A Question of Competing Rights, Priorities, and Principles: A Postscript to the Robert Wood Johnson Foundation Symposium on the Ethics of Childhood Obesity Policy .Prev Chronic Dis . 2011 Sep;8(5):A97.

35. Alzamil H, Meo SA.Medical students' readiness and perceptions about Interprofessional Education: A cross sectional study. Pak J Med Sci. 2020 MayJun;36(4):693-698.

36. Maini A, Fyfe M, Kumar S. Medical students as health coaches: adding value for patients and students. BMC Med Educ. 2020 Jun 3;20(1):182.

37. Alzamil H, Meo SA.Medical students' readiness and perceptions about Interprofessional Education: A cross sectional study. Pak J Med Sci. 2020 MayJun;36(4):693-698.

38. Maini A, Fyfe M, Kumar S. Medical students as health coaches: adding value for patients and students. BMC Med Educ. 2020 Jun 3;20(1):182.

39. Mehta HS, Taraporevala VJ: Medical law and ethics in India. Bombay: The Bombay Samachar Private Ltd., 1963.

40. Jones JW, McCullough LB. Obligations and frustrations with high-risk patients: ethics of physicians' evaluations. J Vasc Surg. 2015 Feb;61(2):533-4

41. Maehle AH. Med Hist. God's ethicist': Albert Moll and his medical ethics in theory and practice. 2012 Apr;56(2):217-36.

42. Singh MM, Garg US, Arora P. Laws applicable to medical practice and hospitals in India. Int J Res Found Hosp Healthc Adm. 2013;1:19-24. 


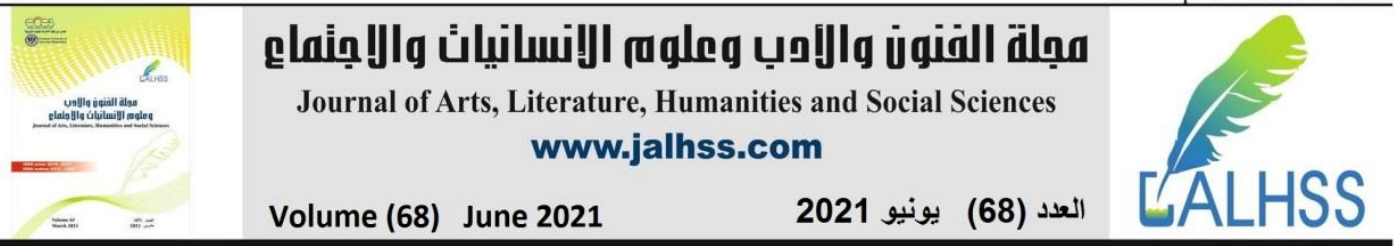

43. Harish D, Kumar A, Singh A. Duties and responsibilities of the medical practitioner, revisited. J Punjab Acad Forensic Med Toxicol. 2012;12:115-20.

44. Sunil Kumar Jatana, Htoo Htoo Kyaw Soe, Khine Lynn Phyu, Htay Lwin, Nan Nitra Than.A Survey on Knowledge and Attitudes towards Medical Ethics among Undergraduate Medical Students. Education 2018; 8(3): 48-53 